Review Article

\title{
A Review of the Wood Pellet Value Chain, Modern Value/Supply Chain Management Approaches, and Value/Supply Chain Models
}

\author{
Natalie M. Hughes, Chander Shahi, and Reino Pulkki \\ Faculty of Natural Resources Management, Lakehead University, 955 Oliver Road, Thunder Bay, ON, Canada P7B 5E1 \\ Correspondence should be addressed to Chander Shahi; cshahi@lakeheadu.ca
}

Received 24 July 2013; Revised 9 October 2013; Accepted 3 December 2013; Published 27 January 2014

Academic Editor: Abdurrahman Saydut

Copyright (C) 2014 Natalie M. Hughes et al. This is an open access article distributed under the Creative Commons Attribution License, which permits unrestricted use, distribution, and reproduction in any medium, provided the original work is properly cited.

We reviewed 153 peer-reviewed sources to provide identification of modern supply chain management techniques and exploration of supply chain modeling, to offer decision support to managers. Ultimately, the review is intended to assist member-companies of supply chains, mainly producers, improve their current management approaches, by directing them to studies that may be suitable for direct application to their supply chains and value chains for improved efficiency and profitability. We found that information on supply chain management and modeling techniques in general is available. However, few Canadian-based published studies exist regarding a demand-driven modeling approach to value/supply chain management for wood pellet production. Only three papers were found specifically on wood pellet value chain analysis. We propose that more studies should be carried out on the value chain of wood pellet manufacturing, as well as demand-driven management and modeling approaches with improved demand forecasting methods.

\section{Introduction}

In a time of great uncertainty and drastic change in the global forestry industry, many companies have found it necessary to shift away from manufacturing conventional forest products and refocus their attention on value-added forest products as well as managing waste (wood) more efficiently. Specifically, the creation of renewable fuel sources for the production of energy, such as wood pellets, has become very popular in recent years $[1,2]$. Wood pellets have many advantages, including high density and heat value and low moisture content, and are relatively convenient to transport and store $[3,4]$. Wood pellets are used for both residential and industrial purposes for the production of heat and/or electricity. There has been an increase in global demand for wood pellets and Canada has responded to this increase by exporting large volumes of wood pellets overseas [5]. A number of wood pellet production plants are emerging globally, thereby creating more competition. Canada is currently among the top producers and exporters of wood pellets $[6,7]$ but due to this increased competition, Canadian manufacturers must find ways to stay competitive in the global market. One way this competitive edge can be achieved is by optimizing production and logistics within the value chain [8].

This paper provides a review of the literature surrounding wood pellet production, the value chain, supply chain, and wood pellet market analysis. Specifically, the four objectives of this paper are (i) to review wood pellet characteristics and production, (ii) to describe and examine the (wood pellet) value chain and the supply chain, (iii) to summarize the broad scope of varying types of value chain and supply chain mathematical modeling approaches, and (iv) to offer our perspective on the gaps in the literature within these three objectives as avenues for potential future research. These four broad objectives contain multiple subobjectives as well. Under objective (i), the components of wood pellet production and the most valuable characteristics of wood pellets will be examined, including modernized certification standards. Objective (ii) will contain a comparison and examination 
of the benefits and hurdles of demand-driven value chain and supply chain management approaches. The importance of demand forecasting to combat uncertainty and enhance leanness and agility within the value chain and supply chain will be evaluated, and a synopsis of the wood pellet market will also be included under this objective. Objective (iii) will highlight the number of specific value chain studies found within the various mathematical modeling approaches.

Value Chain is a concept introduced by Porter [9] that describes a chain of key activities performed within an organization that generates value relating to a product (or service). The value chain tracks the activities required to bring a product (or service) from its conception to fruition in terms of the value that is added to the product (or service) as it moves through the supply chain, which consists of the set of processes required for its completion and delivery [9]. The value chain serves to create an understanding of how, where, and how much of the value created by the product is achieved at various product refinement stages throughout the supply chain. The premise is that each activity along the value chain will create value that exceeds the cost of providing the product (or service), therefore resulting in net profit for the company [10-13]. The goal of value chain optimization is to maximize the value achieved at each stage throughout the supply chain, while minimizing costs. The value chain, even though it is based on internal operations, also has connections with suppliers and retailers, and competition between any of them will damage the entire chain [14]. Porter [9] also emphasized the importance of cost reduction and/or reconfiguration of the value chain in order to obtain a competitive advantage in the marketplace. Value chains differ dramatically, based on the type of product being produced, and no single chain may be used to satisfy one industry [14]. Sathre and Gustavsson [15] emphasized that linking product processes and byproducts provides a beneficial approach for individual firms to add value and increase profit.

A set of firms or a linkage of separate agents, each with their own individual value chains that pass materials forward and bring products or services to the market, is called a supply chain [9]. During this review, it became apparent that there is some ambiguity about the concept of the value chain versus the supply chain. Many of the articles and reports we reviewed offered no differentiation between the two chains and in many cases used the two terms interchangeably. However, Mentzer et al. [16] sorted through the multitudes of varying definitions to provide a more cohesive view of the supply chain and defined supply chain "as a set of three or more entities (organizations or individuals) directly involved in the upstream and downstream flows of products, services, finances, and/or information from a source to a customer." Despite this definition, confusion unfortunately still exists as evidenced by this review.

The value chain and, therefore, the supply chain can become both more productive and profitable if companies focus more of their attention on total supply chain costs instead of just parts of the supply chain in order to optimize performance and revenue [17-21]. Value chain optimization involves coordination between a (manufacturing) firm's various nodes, of the supply chain, through appropriate value chain governance at the operational level, which will allow for the overall supply chain to become more efficient as well [8]. Wood pellet manufacturers and other industry stakeholders need a precise understanding about distribution channels, sustainability, long-term forecasting, and methods to improve their operations within the wood pellet supply chain, to ultimately improve their value chain. Different operational management methods of the supply chain need to be identified for improvement, and the exploration of different modeling techniques will help in determining the best fit for wood pellet supply chain modeling under changing (market) conditions. In this paper, our examination of the peer-reviewed literature available to date provides this identification and exploration through a summary of the existence, and merit, of modern supply chain management techniques, while also gathering information on modeling techniques to support managerial decisionmaking. This summary allows member-companies of supply chains, mainly producers, to recognize shortcomings of their current management approaches and provides an excellent starting point from which an in-depth analysis of specific management techniques may be executed. Implementation of techniques most conducive to achieving improved efficiency and profitability of the operations of specific companies, and their supply chains, is the long-term goal of this review paper.

We have arranged this paper as follows. The methods section describes and presents the number of papers we reviewed in an organized fashion, relating to each objective. The results and discussion section contains subsections for each objective and explains the number of papers we found for objectives (i) to (iii), relative to the total number of papers we reviewed. We discuss the main points of the reviewed papers and how they relate to each objective and subobjective in the subsections of the results and discussion section. Under the sub-section for objective (iv) we highlight the literature gaps we discovered while searching for peer-reviewed studies relating to objectives (i) to (iii) and provide recommendations for future studies to fill these gaps. We conclude the paper with a recap of the main findings of this review and the benefit of filling the literature gaps we have highlighted.

\section{Methods}

This section describes the number of papers we reviewed and how we catalogued them under objectives and subobjectives. We examined a total of 153 sources and categorized them relative to the first three objectives of this research paper (Figure 1). We reviewed a total of 23 journal articles and reports related to wood pellet production, characteristics, and certification in order to achieve objective (i) (Figures 1 and 2). We researched value chain and supply chain management perspectives through examination of 68 peerreviewed publications to fulfill objective (ii) (Figures 1 and 3). For execution of objective (iii) we reviewed 62 peer-reviewed publications in which models were developed to improve either value chain or supply chain efficiency (Figures 1 and 4). We met objective (iv) through the realization of objectives (i) to (iii). 


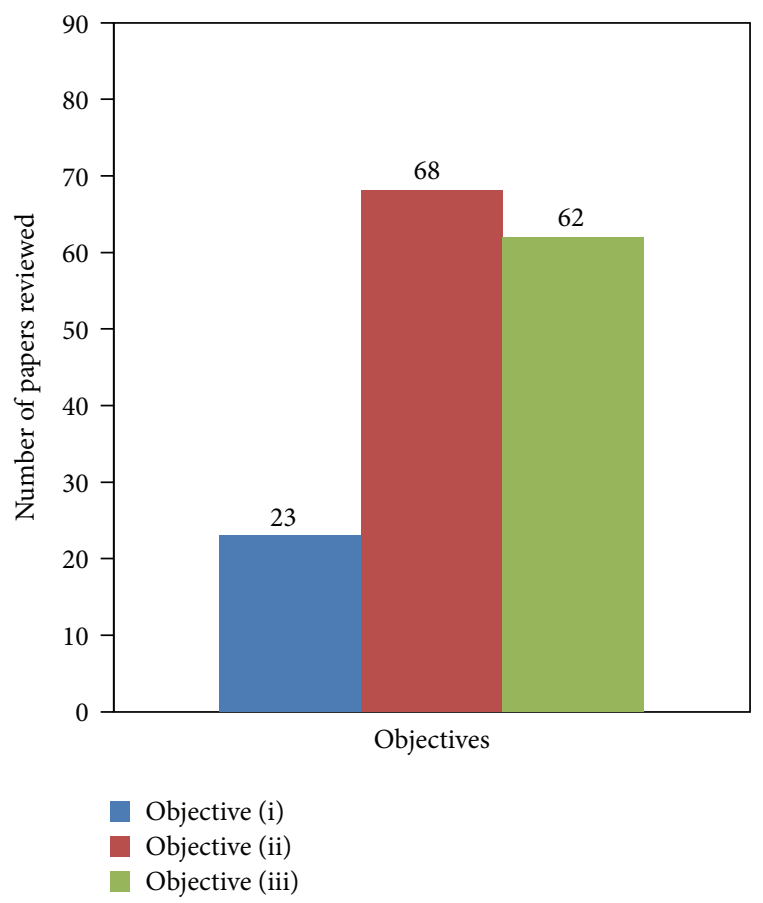

FIGURE 1: Total publications reviewed for objectives (i), (ii), and (iii).

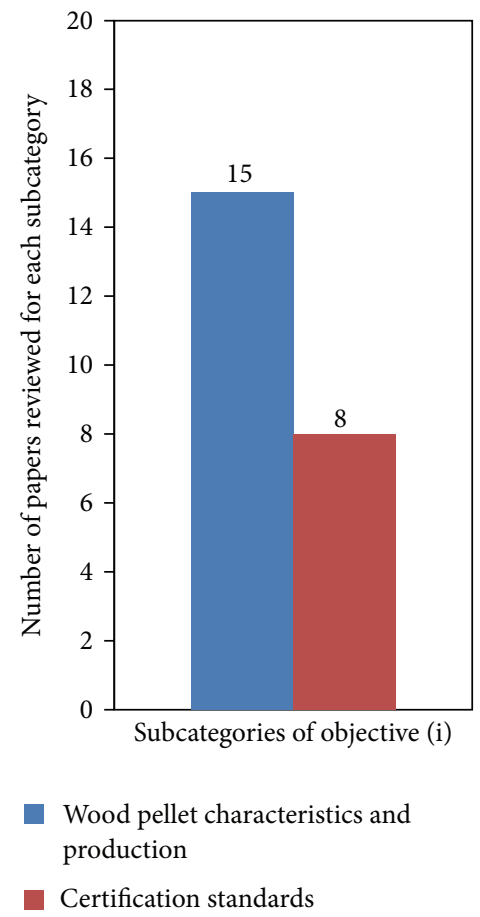

Figure 2: Publications reviewed for the subcategories of objective (i).

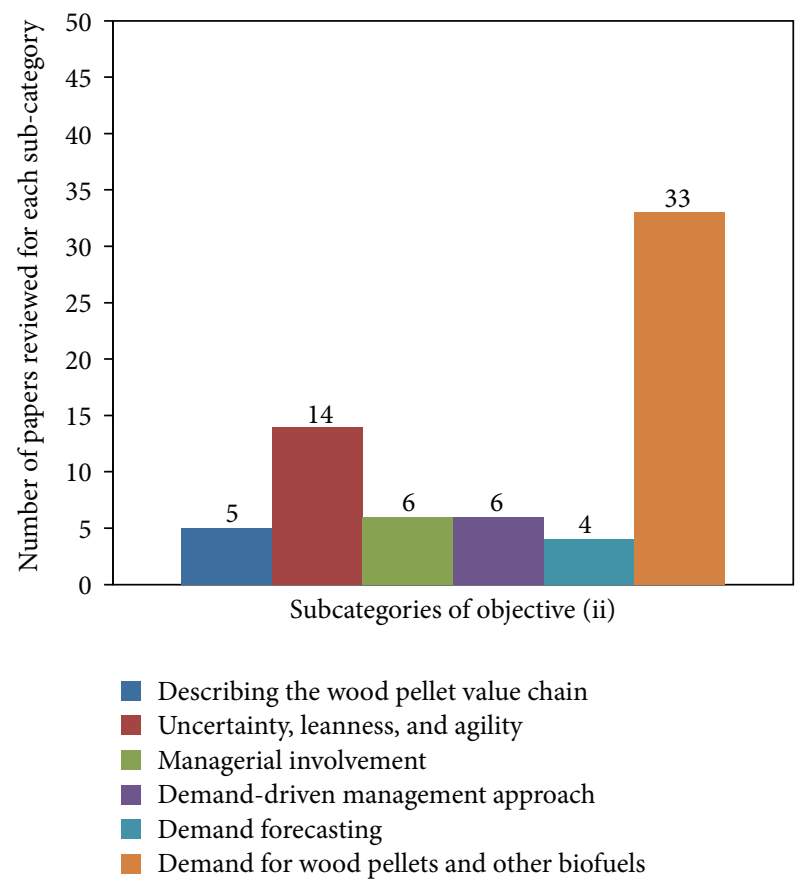

Figure 3: Publications reviewed for the subcategories of objective (ii).

\section{Results and Discussion}

In this section, findings from our literature search relating to each specific objective are discussed in terms of the relative number of studies we found concerning each objective. The information extracted from these studies is summarized in order to determine the literature gaps that may be filled by future research.

3.1. Objective (i): Wood Pellet Production and Characteristics. Of the 153 papers reviewed, we found only 15 (10\%) describing the production process of wood pellets and/or explained their beneficial characteristics, of which only three (2\%) gave an indepth analysis [3,22, 23], one of which was a Canadian-based study [23].

The basic steps in the pellet production process (from raw materials to pellets) include (i) drying, (ii) grinding, (iii) conditioning, (iv) pelletizing, (v) screening for fine separation, and (vi) packaging/storing of final product [22, 24-27]. Raw materials for pelletization in many countries worldwide are mainly wood shavings and sawdust from the wood processing industry $[25,26,28]$. To create one tonne of pellets with moisture content between 7 and $10 \%$, an approximate volume of $7.5 \mathrm{~m}^{3}$ of sawdust must be processed (at moisture content of 50\%) [1,3]. Once formed and cooled, pellets are either filled automatically into small (i.e., 40 pound) bags for residential consumers or large bags (i.e., 650 kilograms) for larger customers or stored in bulk in silos or halls $[3,22]$. Raw materials cost and (when using wet raw materials) drying costs comprise the majority of total pellet 


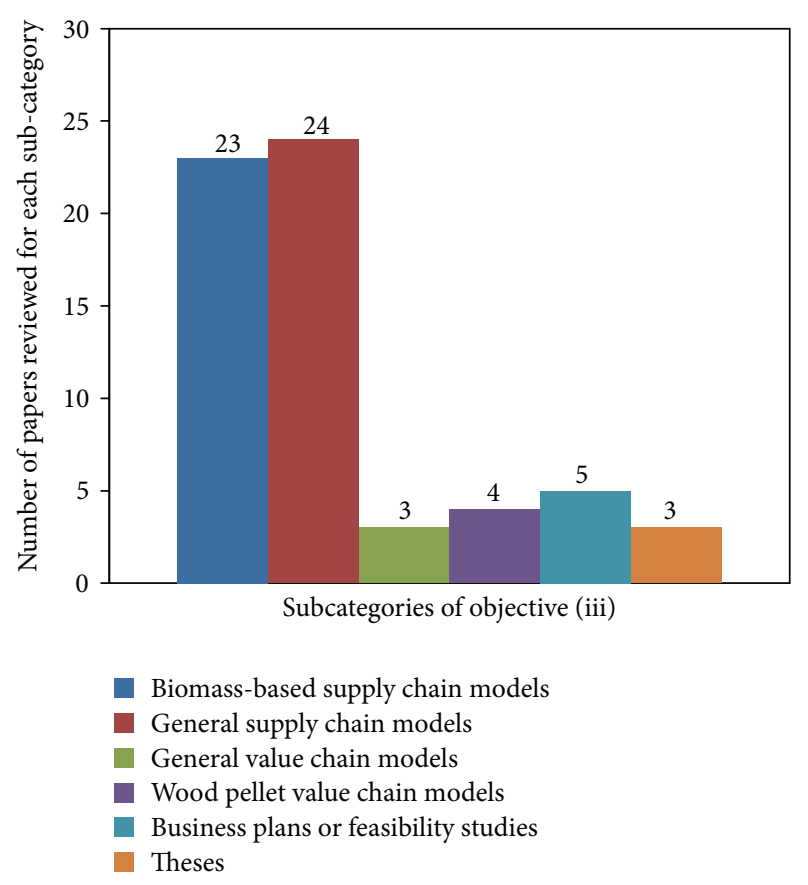

FIgURE 4: Publications reviewed for the subcategories of objective (iii).

production expenses [28-31]. As pellet-plant size decreases, production cost increases $[32,33]$.

Densification of wood pellets, as a result of compaction, allows for greater homogeneity of the product, enhanced combustion efficiency, and efficient transport and storage [30, 34-36]. A study by $\mathrm{Pa}$ et al. [37] indicates that the combustion of wood pellets requires less primary energy than the combustion of undensified wood waste and that pellets emit lower levels of harmful emissions (i.e., carbon monoxide, nitric oxide, and particulate matter) than wood waste. Sultana and Kumar [38] used PROMTHEE (Preference Ranking Organization Method for Enrichment and Evaluation) to determine that wood pellets were superior to pellets made of other feedstocks, namely, straw, switchgrass, alfalfa, and poultry litter. This method was used considering 11 criteria, both quantitative and qualitative, under three differently weighted scenarios for use in large-scale heat and power generation plants. The results indicate that wood pellets were the "best source of energy" for all scenarios. Naik et al.s [39] study also found specifically that Canadian pinewood had the best physicochemical characteristics and lowest detrimental emission levels as compared with other biomass samples.

Wood pellets are used for small-scale/residential systems, district heating, and cofiring with coal in large-scale power plants $[5,25,34]$. District heating refers to a network-bound heating plant that is centrally located and connected to a number of buildings (i.e., a residential "district" comprised of households or schools, smaller businesses, etc.) [3]. In North America, wood pellets are most commonly used in small-scale/residential heating systems, and modern versions of these small-scale systems have become automated to the point that they require only a minor amount of maintenance $[3,30]$. High standards for pellet fuel quality are required in the residential sector, with a high level of homogeneity required to achieve fully automated operation and complete combustion in small-scale furnaces $[22,40]$.

3.1.1. ENplus Certification System. Prior to the implementation of the ENplus Certification System in 2011, European, Canadian, and US pellet-producing companies had significant variation in official country quality standards and guidelines [41-43]. We found only a few publications about pellet certification (Figure 2), presumably because of the lack of guideline cohesiveness and only recent development of the ENplus system. The ENplus System allows for convenient and effective compliance with the European standard EN 14961-2 [44]. The purpose of this certification system is to establish a standardized quality regime for wood pellets for heating and combined heat and power (CHP) up to $1 \mathrm{MW}$ output power in residential, commercial, and public buildings [44]. The System will create a "level playing field" for pellet producers and will boost consumers' confidence that they are receiving a quality product [45]. Under ENplus standards operational processes including production, logistics, and delivery are controlled and made transparent by defining the requirements for technical facilities, operational procedures, and documentation [44]. This transparency allows for quick and easy problem identification and solving, therefore minimizing downtime of production facilities. The German Pellet Institute (DEPI) developed the ENplus System and licensed it to the European Pellet Council (EPC), which is an organization within the European Biomass Association (AEBIOM) [44]. The specifications of the System include three classes of pellet quality: ENplus-A1, ENPlus-A2, and EN-B [44]. ENplus-A1 is used in residential boilers or stoves and is the premium class of pellets, producing the least amount of ash and meeting the highest standards [41]. ENplus-A2 pellets produce a higher amount of ash during combustion and are used in larger boiler systems [41]. The industrial grade of pellets under ENplus is classed as EN-B [41].

Table 1 summarizes the spectrum of the crucial pellet parameters for each class. Additives to improve fuel quality must not exceed $2 \%$ of the total mass of the pellets $(\leq 1.8 \%$ of the total pellet mass in production and $\leq 0.2 \%$ of the total pellet mass after production) [44]. Each certified producer (and trader) must display the ENplus certification seal on their product [44]. Producers and traders of wood pellets that have adopted ENplus certification standards are found in countries around the world including Austria, Belgium, Canada, Croatia, Czech Republic, Denmark, France, Germany, Italy, Lithuania, Poland, Portugal, Romania, Slovenia, Slovakia, Spain, Switzerland, the Netherlands, the US, and the UK [41]. Canada is making the switch to the ENplus standard; The Wood Pellet Association of Canada has already applied to receive the ENplus license for Canada [46].

3.2. Objective (ii): Value Chain and Supply Chain Management. As demonstrated in Figure 3, many studies were found 
TABLE 1: Ranges of EN 14961-2 values for the most crucial wood pellet parameters.

\begin{tabular}{|c|c|c|c|c|c|}
\hline Property & Unit $^{(*)}$ & ENplus-A1 & ENplus-A2 & EN-B & Testing standard \\
\hline Diameter & $\mathrm{mm}$ & 6 or 8 & 6 or 8 & 6 or 8 & EN 16127 \\
\hline Length & $\mathrm{mm}$ & $3.15 \leq \mathrm{L} \leq 40^{(3)}$ & $3.15 \leq \mathrm{L} \leq 40^{(3)}$ & $3.15 \leq \mathrm{L} \leq 40^{(3)}$ & EN 16127 \\
\hline Moisture content & $\mathrm{w}-\%^{(1)}$ & $\leq 10$ & $\leq 10$ & $\leq 10$ & EN 14774-1 \\
\hline Ash content & $\mathrm{W}-\%^{(2)}$ & $\leq 0.7$ & $\leq 1.5$ & $\leq 3.0$ & $\mathrm{EN} 14775\left(550^{\circ} \mathrm{C}\right)$ \\
\hline Mechanical durability & $\mathrm{w}-\%^{(1)}$ & $\geq 97.5^{(4)}$ & $\geq 97.5^{(4)}$ & $\geq 96.5^{(4)}$ & EN 15210-1 \\
\hline Fines $(<3.15 \mathrm{~mm})$ & $\mathrm{w}-\%^{(1)}$ & $<1$ & $<1$ & $<1$ & EN 15210-1 \\
\hline Net calorific value & $\mathrm{MJ} / \mathrm{kg}^{(1)}$ & $16.5 \leq \mathrm{Q} \leq 19$ & $16.3 \leq \mathrm{Q} \leq 19$ & $16.0 \leq \mathrm{Q} \leq 19$ & EN 14918 \\
\hline Bulk density & $\mathrm{kg} / \mathrm{m}^{3}$ & $\geq 600$ & $\geq 600$ & $\geq 600$ & EN 15103 \\
\hline Nitrogen content & $\mathrm{W}-\%^{(2)}$ & $\leq 0.3$ & $\leq 0.5$ & $\leq 1.0$ & EN 15104 \\
\hline Sulfur content & $\mathrm{W}-\%^{(2)}$ & $\leq 0.03$ & $\leq 0.03$ & $\leq 0.04$ & EN 15289 \\
\hline Chlorine content & $\mathrm{w}-\%^{(2)}$ & $\leq 0.02$ & $\leq 0.02$ & $\leq 0.03$ & EN 15289 \\
\hline Ash melting behaviour ${ }^{4}$ & ${ }^{\circ} \mathrm{C}$ & $\geq 1200$ & $\geq 1100$ & $\geq 1100$ & EN 15370 \\
\hline
\end{tabular}

on supply chain and value chain management. However, very few studies specifically described the value chain [8, 18, 47]. The value chain of wood pellet manufacturers includes the determination of the value associated with each stage of the supply chain, which includes raw material procurement, inbound logistics of raw materials, processing of raw materials into pellets, and outbound logistics to the end consumer [24]. Procurement includes the location of raw materials, the species of raw materials in existence for wood pellet usage, and the original state of these accessible materials (i.e., roundwood, wood chips, sawdust, or wood shavings). Inbound logistics is the method of transportation required to move the raw material from its original location to the manufacturing plant for processing and includes scheduling decisions. Processing includes drying, grinding, pressing, cooling, and bagging/storage. Outbound logistics is the method of transportation used to deliver the pellets to the end consumer and also includes scheduling decisions.

Transportation scheduling (logistics) is a very important component of the wood pellet value chain, as fuel prices and operator wages continue to increase, therefore requiring optimal transportation decisions to be made to avoid unnecessary costs. Pettersson and Segerstedt [48] define logistics cost as "cost components related to distribution or transportation cost and cost for warehouses," in an attempt to offer clarity to the term and separate it from the term "supply chain cost," which they define as "all relevant costs in the supply chain of the company or organisation in question." In an expansive nation such as Canada, it is not feasible to transport cutter shavings, sawdust, and/or wood chips over long distances $[4,6]$. It is worthwhile to transport the densified wood pellets, as they have a high BTU/volume ratio; however, the longer the haul distance for raw materials or finished pellets is, the less cost-effective it is for the producer [6]. Well-developed, seamless connections to marketing-sales and order-delivery processes are needed for efficient, cost-effective value chain coordination (i.e., backhauling) [49-51]. Rail transport is a very efficient and cost-effective means of moving wood pellets; however, not all producers have direct access to railways. Rail [52] has begun to more aggressively market their wood pellet transportation opportunities to Canadian producers. They offer the flexibility to ship wood pellets in bulk, bags, boxcars, and intermodal containers. Rail [52] ships over $800,000 \mathrm{t}$ of wood pellets annually and is ranked as "North America's number 1 mover of forest products."

3.2.1. Uncertainty, Leanness, and Agility. When considering modeling of the (wood pellet) value chain within the manufacturing firm, agility must be achieved to account for differences in specifications and types of wood pellets, as well as differences in procurement, processing, and distribution methods and locations. Value chain models should be created with the intent to readily change these inputs based on market demand and should reduce operational planning cycles [49]. Operational planning cycles include all activities that must be planned to ensure successful operation of a business in a very short-term time period (i.e., one week) [49]. In recent years the trend in supply chain management has been to make supply chains (and their integrated value chains) more agile, flexible, and responsive [53-57]. This trend is illustrated by Figure 3, which shows that we reviewed 14 publications specifically addressing these supply chain attributes.

Mathematical models have been used as decision support tools to assist managers in decision-making processes for strategic, tactical, and operational level planning. Operational-level management must focus on short-term productivity and process optimization to meet changing market trends [58]. Cost forecasting under uncertainty can lead to inaccurate model results; therefore, uncertainty must be remedied by increasing clarity and accuracy of input information [59]. "Decisions are made under certainty when 
perfect information is available and under uncertainty when one has only partial (or imperfect) information" [50]. Deterministic models serve as a "solid foundation" for value chain network design; however, deterministic models do not handle uncertainties and changes in information [50]. Therefore, stochastic models must be used which take into account realistic factors that affect business operations, including (but not limited to) raw material prices, energy costs, market demand for the end product(s), the cost of labour, retail price(s) of the finished product(s), and exchange rates [50, $60]$.

Leanness in a firm's value chain refers to its ability to "do more with less" and minimize (or eliminate) waste in its operations with cost leadership and cost performance strategies [61-64]. Agility in a firm's value chain encompasses operational flexibility performance and responsiveness to changes in information, such as product volume and/or logistics scheduling fluctuations [65-68]. Agility must also be applied not only within the individual firm's value chain but also throughout the supply chain as part of the partner selection process to create agile supply chains [69]. Both agility and leanness are strategies useful for developing or maintaining a competitive advantage in an uncertain marketplace.

3.2.2. Managerial Involvement. During this review, we uncovered six papers addressing the importance of managerial involvement in value chain and supply chain optimization [70-72] (Figure 3). Supply and demand are dynamic and ongoing processes; and, therefore, managing the value chain of a company should be considered as an ongoing relationship between suppliers, the manufacturing firm and, end consumers [71]. The more involved management becomes with the value chain, the more they may visualize linkages of the value chain with the overall marketing strategy and goals of the firm, and the more likely management is to follow through with the successful application of the value chain at the operational level [72]. Gooch [70] found that, even when value chain optimization strategies are implemented within a firm, human resistance is inevitable and can seriously detract from the effectiveness of the management plan. Sometimes managers are even confused by the propositions and/or realize that the value chain model is being incorrectly used and therefore refuse to support it rather than work to improve its usage [64]. Unfortunately this resistance to change seriously affects the performance of the firm.

When dealing with complex value chains, identification of the critical value network locations is a useful managerial approach [73]. Lind et al. [13] emphasized that managing the working capital (short-term finance flow) of a company and its supply chain should be a major focus instead of just managing the flow of goods through the supply chain. Cantor and Macdonald [74] reviewed management problem-solving approaches within the supply chain and found that a more abstract approach to decision making may actually achieve better overall results than a more concrete approach. Cantor and Macdonald [74] discussed the fact that having complex, system-wide knowledge (more information) overwhelmed many managers, leading to poor decision making. Therefore, the use of a decision support system can simplify the overload of information and help managers make better decisions while still having all available information at their fingertips.

3.2.3. Demand-Driven Management Approach. Demanddriven supply networks aim to link the supply/production rate directly to the level of actual demand for a specified time period in order to enable the manufacturer to respond in real-time to shifts in the level of demand and gain insight into general demand trends for their product(s) [49, 75]. The "upstream" component of the manufacturing value chain is the origin of the raw materials used to produce a product and the transportation of these materials to the processing facility, while the "downstream" component of the value chain follows processing to distribution of the final product to the end consumers [76]. Most companies, by default, examine their supply chains and value chains from an "upstream to downstream" perspective (as a directional flow), meaning that they operate by creating the product based on capacity, with some concept of forecasted market demand, and "push" the product out into the marketplace and also examine associated value creation in this manner [77-79]. Neumann et al. [62] conducted surveys of various companies only to find that even when it came to incorporating lean production techniques, very few companies used a demandpull strategy. The findings of this review are in accordance with those of Neumann et al. [62], as only six (9\%) of the 68 papers studied for objective 2 discussed the effectiveness of demand-driven management approaches [49, 75, 76, 8082] (Figure 3). Demand Forecasting approaches were also considered by three of the six papers in objective 2 addressing demand-driven management $[49,75,82]$.

Demand-driven management adopts the value chain's downstream to upstream perspective (as a directional flow) and applies it to the supply chain. This application allows for production to become a reactive process based on the signals sent by real-time demand to the upstream (procurement) end of the supply chain and the product is "pulled" through the supply chain and/or value chain by the quantity demanded, instead of being "pushed" out into the market $[83,84]$. Demand-driven models, used to support demand-driven management techniques, are very advantageous for many reasons. These reduce, or eliminate, inefficiencies throughout the supply chain and allow for a "smooth product flow", have shown significant improvements in utilization processes, improve inventory management and achieve optimal production capacities, and are more successful at responding to supply fluctuations $[84,85]$.

3.2.4. Demand Forecasting. Demand forecasts are crucial to provide input for demand-driven planning systems. Multiple approaches are available to forecast demand. Vinterbäck [86], and Hosoda, and Disney [87] discuss some of these approaches, including exponential smoothing, the naïve approach, moving average, autoregressive (AR), autoregressive integrated moving average (ARIMA), autoregressive extra (ARX), vector autoregressive (VAR), neural networks 
and the quantile regression method. However, these methods have not been proven to be overly effective and still allow for inaccurate demand prediction at each level throughout the supply chain, resulting in the bullwhip effect, which is amplification in demand variability when moving upstream through a value chain or supply chain [88]. Therefore, we are considering the new approaches currently being researched to increase the forecasting accuracy. Multilayer perception (MLP) is an approach that generalizes either linear or nonlinear functional relationships between inputs and outputs [88]. Yousefi et al. [82] designed a comprehensive demand response (CDR) model for a Retail Energy Provider agent in an agent-based retail environment to offer real-time energy prices to customers. Yousefi et al. [82] found that the CDR model gave a better representation of customers' historical behavior for future demand prediction. We only found four papers in our review that addressed demand forecasting $[50,79,87,88]$, while another three papers, which we categorized as demand-driven management papers, also addressed demand forecasting approaches $[49,75,82]$.

\subsubsection{Demand for Wood Pellets and Other Biofuels. Of the 68} papers reviewed for objective 2, 33 (49\%) considered market demand for wood pellets and other biofuels (Figure 3). North America began producing wood pellets for a small niche market in the 1930s, with a significant market growth spurt occurring in the 1970s, followed by rapid market development in the 1990s as a result of increased consumption in Europe $[89,90]$. In Canada in 1997 pellet production was only $173,000 \mathrm{t}$, of which roughly two-thirds were exported to the US, but from 1997 to 2007 Canada went from exporting $0 \%$ to $63 \%$ of its pellets to the European market, which displaced the US from its position as Canada's major trade partner [3]. In 2010, wood pellet production was less than $70 \%$ of design capacity in Europe, implying a lack of natural resources for pellet production, and, therefore, indicating a need for pellet import [5]. Imported biomass comprises between $21 \%$ and $43 \%$ of Europe's total available biomass [6]. Canada is now one of the world's leaders with regard to production and trade success of wood pellets because of many contributing factors, including its surplus of natural resources, low-cost mill residue, excess pellet production capacity, and abundance of export opportunities [91-94].

Obernberger and Thek's [3] prognosis for Canada was for $5.5 \mathrm{Mt}$ to be produced in 2010. However, the production capacity of Canada in 2010 was only $2.08 \mathrm{Mt}$ per year and in 2011 it expanded to $3.22 \mathrm{Mt}$ per year (a 55\% growth from 2010 to 2011). However, not all production plants are (or were) operating at full capacity due to market conditions $[95,96]$.

Market studies on Canada and other relevant countries show that Canada is lacking in domestic wood pellet demand as compared with these other countries; therefore most of Canada's pellet production is exported [95, 97]. However, some of these studies have noted that there is a rising trend in Canada's domestic consumption of wood pellets and that Canada has great potential for growth with regard to domestic pellet consumption $[92,94,98]$. Junginger et al. $[6,98]$ identify logistics as the most influential trade barrier for wood pellets, while development of technical standards presents itself as a major opportunity for wood pellet trade. Wolf et al. [31] identified the need to more efficiently produce biomass in order to meet expanding market demand and studied the effectiveness and feasibility of biofuel production in the forestry industry.

There has been rapid growth in the worldwide production and consumption of wood pellets and other biomasses within the last decade $[99,100]$. Canada, the US, Korea, and countries throughout Europe exhibit this global trend [101-110]. A factor contributing to the onset of this trend is favourable government policy implementation, which has allowed for an effective increase in pellet production and consumption [99]. Provincial governments throughout Canada have successfully implemented various initiatives to promote renewable energy production and usage. For example, Ontario's Green Energy Act of 2009 applied a Feedin-Tariff (FIT) program that offers price incentives for new electrical generating stations that are fueled by renewable resources [111]. Aboriginal, or first nation, communities in Ontario have also begun the process of adopting renewable energy initiatives. The community of Pic River First Nation has various current and future renewable energy projects and is actively participating in knowledge and information sharing with other first nations communities across Ontario and Canada [112].

Average worldwide demand (consumption) for wood pellets increased from 3.28 Mt in 2003 to $10.54 \mathrm{Mt}$ in 2007 (a $41.7 \%$ increase), average worldwide production increased from 3.38 Mt in 2003 to $10.54 \mathrm{Mt}$ in 2007 (a 40.5\% increase), and average worldwide capacity increased from $4.5 \mathrm{Mt}$ in 2003 to $15.0 \mathrm{Mt}$ in 2007 (a 43.1\% increase) [5]. Sweden is one of the world's largest producers and consumers of wood pellets, due mainly to its favourable taxation system towards biofuels, ubiquitous district heating systems, and abundance of raw materials [97]. Pellet usage for heating/energy allows for improved fuel supply security (from a renewable resource viewpoint) and stimulates local and regional job creation and overall economic development [110]. Generally, the availability of forest resources, the demand for forest fuels, and machine and labour costs are the defining factors behind (wood pellet) prices [32, 34]. Other factors contributing to the global success of the wood pellet industry include the automation of heating systems, logistics infrastructure, national funding systems coupled with marketing programs and public awareness campaigns, and price increases in the oil and gas sector [113]. As the marketplace expands and demand for wood pellets increases, if the demand for pellets exceeds the current capacity of production plants, they will have to increase capacity in order to satisfy demand and remain competitive [32].

\subsection{Objective (iii): Supply Chain and Value Chain Models.} Papageorgiou [60] identifies two broad categories for supply chain models: mathematical programming models and simulation models. He explains that mathematical models are used for optimizing high-level decisions with an aggregate view of operational processes, while simulation-based models 
TABLE 2: Categorization of model types in reviewed papers.

\begin{tabular}{|c|c|c|c|c|}
\hline \multicolumn{2}{|c|}{ Type of study } & \multirow{5}{*}{ 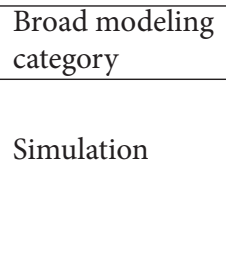 } & \multirow{5}{*}{$\begin{array}{l}\text { Type of modeling approach } \\
\text { Simulation } \\
\text { Demand driven } \\
\text { Simulation-based fuzzy inventory } \\
\text { Integrated biomass supply and logistics (ISBAL) } \\
\text { modeling environment-dynamic simulation }\end{array}$} & \multirow{5}{*}{$\begin{array}{c}\text { Authors using the } \\
\text { modeling approach } \\
{[80,128]} \\
{[83,84]} \\
{[129]} \\
{[130]}\end{array}$} \\
\hline \multirow{4}{*}{$\begin{array}{l}\text { Supply chain } \\
\text { models }\end{array}$} & \multirow{4}{*}{$\begin{array}{l}\text { Biomass supply } \\
\text { chain models }\end{array}$} & & & \\
\hline & & & & \\
\hline & & & & \\
\hline & & & & \\
\hline \multirow{15}{*}{$\begin{array}{l}\text { Supply chain } \\
\text { models }\end{array}$} & \multirow{15}{*}{$\begin{array}{l}\text { Biomass supply } \\
\text { chain models }\end{array}$} & \multirow{15}{*}{$\begin{array}{l}\text { Mathematical } \\
\text { programming }\end{array}$} & Dynamic, nonlinear mixed integer & {$[131,132]$} \\
\hline & & & Dynamic, linear mixed integer & {$[114,133]$} \\
\hline & & & Scenario-based optimization & {$[32,125]$} \\
\hline & & & Agent-based models (ABMs) & {$[134]$} \\
\hline & & & $\begin{array}{l}\text { Land-suitability model (LSM) using analytic hierarchy } \\
\text { process (AHP) }\end{array}$ & {$[135]$} \\
\hline & & & Power function utilization & {$[33]$} \\
\hline & & & Spatial partial equilibrium & {$[136]$} \\
\hline & & & Technoeconomic & {$[36,126]$} \\
\hline & & & Game theoretic approach & [127] \\
\hline & & & Mixed integer & [137] \\
\hline & & & Mixed integer linear programming (MILP) & [138] \\
\hline & & & Linear programming network & [139] \\
\hline & & & $\begin{array}{l}\text { Process network synthesis (PNS) two-level process } \\
\text { graph (P-graph) approach }\end{array}$ & {$[31,140]$} \\
\hline & & & Newsvendor economic & [141] \\
\hline & & & Integrated optimization & {$[142]$} \\
\hline $\begin{array}{l}\text { Supply chain } \\
\text { models }\end{array}$ & $\begin{array}{l}\text { General supply } \\
\text { chain models }\end{array}$ & Simulation & Simulation & {$[21,143,144]$} \\
\hline \multirow{10}{*}{$\begin{array}{l}\text { Supply chain } \\
\text { models }\end{array}$} & \multirow{10}{*}{$\begin{array}{l}\text { General supply } \\
\text { chain models }\end{array}$} & \multirow{10}{*}{$\begin{array}{l}\text { Mathematical } \\
\text { programming }\end{array}$} & Demand driven & {$[83]$} \\
\hline & & & Agent-based models (ABMs) & {$[78]$} \\
\hline & & & Closed-loop optimization & {$[53]$} \\
\hline & & & Mixed integer & {$[145]$} \\
\hline & & & Lead-time inventory & {$[65,146,147]$} \\
\hline & & & Stochastic network & {$[148]$} \\
\hline & & & Fuzzy programming & {$[149]$} \\
\hline & & & Mixed integer linear programming (MILP) & {$[150-152]$} \\
\hline & & & Integrated business planning (IBP) matrix & [153] \\
\hline & & & Genetic algorithms & {$[57,154,155]$} \\
\hline \multirow{3}{*}{$\begin{array}{l}\text { Value chain } \\
\text { models }\end{array}$} & \multirow{3}{*}{$\begin{array}{l}\text { General value } \\
\text { chain models }\end{array}$} & \multirow{3}{*}{$\begin{array}{l}\text { Mathematical } \\
\text { programming }\end{array}$} & Mixed integer nonlinear programming & {$[115,156]$} \\
\hline & & & $\begin{array}{l}\text { Object oriented programming approach with ecological } \\
\text { mass balance }\end{array}$ & [116] \\
\hline & & & Analytic network process (ANP) & {$[47]$} \\
\hline $\begin{array}{l}\text { Value chain } \\
\text { models }\end{array}$ & $\begin{array}{l}\text { Wood pellet } \\
\text { value chain } \\
\text { models }\end{array}$ & Simulation & Inventory management (Pell-Sim) & {$[86]$} \\
\hline \multirow{3}{*}{$\begin{array}{l}\text { Value chain } \\
\text { models }\end{array}$} & \multirow{3}{*}{$\begin{array}{l}\text { Wood pellet } \\
\text { value chain } \\
\text { models }\end{array}$} & \multirow{3}{*}{$\begin{array}{l}\text { Mathematical } \\
\text { programming }\end{array}$} & Win-win optimization & [113] \\
\hline & & & Technoeconomic & {$[30]$} \\
\hline & & & Static partial equilibrium & {$[24]$} \\
\hline \multirow{2}{*}{ Other } & \multirow{2}{*}{$\begin{array}{l}\text { Wood pellet } \\
\text { theses }\end{array}$} & \multirow{2}{*}{$\begin{array}{l}\text { Mathematical } \\
\text { programming }\end{array}$} & Linear multicommodity network flow & {$[123]$} \\
\hline & & & Scenario-based financial & {$[122,124]$} \\
\hline Other & $\begin{array}{l}\text { Biomass } \\
\text { business plans }\end{array}$ & $\begin{array}{l}\text { Mathematical } \\
\text { programming }\end{array}$ & Financial-based & {$[117,118]$} \\
\hline Other & $\begin{array}{l}\text { Wood pellet } \\
\text { business plans }\end{array}$ & $\begin{array}{l}\text { Mathematical } \\
\text { programming }\end{array}$ & Financial-based & {$[119,120]$} \\
\hline
\end{tabular}

are more accurate as they study detailed, dynamic operations under uncertainty.

3.3.1. Supply Chain Models. We discovered that many general supply chain models have been developed, covering a wide variety of products (Table 2). Biomass includes all plant and plant-derived materials (including animal manure!) that can be considered a part of the present carbon cycle [114]. Using this broad definition, there have also been many supply chain models created relating to biomass (Table 2).

3.3.2. Value Chain Models. We found that relatively few academic research papers have been published specifically on value chain modeling $[115,116]$. There were three studies 
found specifically on wood pellet value chain analysis [24, $30,113]$. Other sources found were five feasibility studies for actual biomass and wood pellet production facilities [117-121] and three university theses on wood pellet production and feasibility [122-124]. Refer to Table 2 below for a comprehensive list.

3.3.3. Demand-Driven Models. Our review uncovered only two papers discussing and utilizing demand-driven approaches to modeling $[83,84]$ and these were both supply chain models (Table 2).

3.4. Objective (iv): Perspective. This section explains the gaps in the existing literature based on the findings of our review for each objective. We identify suggestions for future studies that may successfully fill in these gaps.

3.4.1. Literature Gaps and Recommendations for Future Research. There is a need for more (Canadian) studies specifically about wood pellet production methods and characteristics. The low number of Canadian-based value chain and supply chain studies indicates a rather large gap that needs to be filled as well. There is a need for more value chain models in general but especially those relating to wood pellet production. Going hand-in-hand with the value chain gap is the gap relating to managerial involvement, as defined in Section 3.2.2. Future studies focused on value chain optimization can be paired with guidelines for convenient and effective managerial execution.

There is also a great need for dynamic, demand-driven models within the value chain and the supply chain. This need may be coupled with the necessity of more accurate and effective demand forecasting methods. By employing capacity-optimization techniques similar to those outlined in previous studies [32, 125-127] pellet production costs may be minimized as a function of plant capacity, utilizing realtime information and emulating stochastic market demand. Following the lead of Trapero et al. [88] and Yousefi et al. [82] and building upon their results would produce cutting-edge demand forecasting methods to improve demand-driven modeling approaches.

\section{Conclusions}

The available literature associated with wood pellet production and characteristics, value/supply chain management concerns and value/supply chain modeling techniques was explored in this review paper. The results show that relatively few published studies provide an in-depth account of wood pellet production, pellet plant feasibility and wood pellet value/supply chain management. There are also very few papers explaining the overall concept of the value chain. We discovered only a small number of Canadian-based studies during this review as well. Future studies to fill these gaps, particularly within the realm of the value chain for Canadian pellet-producing companies, should be conducted. These studies would not only be beneficial to the producers but also to the companies linked to the producers within the supply chain. Currently, measures are being taken to expand Canada's bioeconomy; therefore new studies demonstrating feasible projects relating to the bioeconomy, with improved supply chains and value chains, are essential to promote this expansion. Implementation of modern demand forecasting and demand-driven supply chain management techniques will improve the operations of current facilities and most effectively manage the operations of new facilities.

\section{Conflict of Interests}

The authors declare that there is no conflict of interests regarding the publication of this paper.

\section{References}

[1] E. Alakangas and M. Virkkunen, EUBIONET II-Biomass Fuel Supply Chains For Solid biofuels, From Small To Large Scale, VTT Technical Research Centre of Finland, Jyväskylä, Finland, 2007.

[2] M. Kennedy, R. Wong, A. Vandenbroek, D. Lovekin, and M. Raynolds, Biomass Sustainability Analysis, An Assessment of Ontario-Sourced Forest-Based Biomass For Electricity Generation, The Pembina Institute, Alberta, Canada, 2011.

[3] I. Obernberger and G. Thek, The Pellet Handbook, the Production and thermal Utilisation of Pellets, Earthscan, London, UK, 2010.

[4] W. Rickerson, T. Halfpenny, and S. Cohan, "The emergence of renewable heating and cooling policy in the United States," Policy and Society, vol. 27, no. 4, pp. 365-377, 2009.

[5] J. H. Peng, H. T. Bi, S. Sokhansanj, J. C. Lim, and S. Melin, "An economical and market analysis of Canadian wood pellets," International Journal of Green Energy, vol. 7, no. 2, pp. 128-142, 2010.

[6] M. Junginger, T. Bolkesjø, D. Bradley et al., "Developments in international bioenergy trade," Biomass and Bioenergy, vol. 32, no. 8, pp. 717-729, 2008.

[7] E. K. Ackom, W. E. Mabee, and J. N. Saddler, "Industrial sustainability of competing wood energy options in Canada," Applied Biochemistry and Biotechnology, vol. 162, no. 8, pp. 2259-2272, 2010.

[8] M. C. Mahutga, "When do value chains go global? A theory of the spatialization of global value chains," Global Networks, vol. 12, no. 1, pp. 1-21, 2012.

[9] M. Porter, Competitive Advantage: Creating and Sustaining Superior Performance, Collier-Macmillan, New York, NY, USA, 1985.

[10] D. W. te Velde, J. Rushton, K. Schreckenberg et al., "Entrepreneurship in value chains of non-timber forest products," Forest Policy and Economics, vol. 8, no. 7, pp. 725-741, 2006.

[11] D. Walters, "Competition, collaboration, and creating value in the value chain," in Modelling Value, Contributions To Management Science: Selected Papers of the 1st International Conference on Value Chain Management, H. Jodlbauer, J. Olhager, and R. J. Schonberger, Eds., pp. 3-36, University of Applied Sciences in Upper Austria, School of Management, Steyr, Austria, 2012.

[12] A. K. N. Aoudji, A. Adégbidi, V. Agbo et al., "Functioning of farm-grown timber value chains: lessons from the smallholderproduced teak (Tectona grandis L.f.) poles value chain in 
Southern Benin," Forest Policy and Economics, vol. 15, pp. 98107, 2012.

[13] L. Lind, M. Pirttilä, S. Viskari, F. Schupp, and T. Kärri, "Working capital management in the automotive industry: financial value chain analysis," Journal of Purchasing and Supply Management, vol. 18, no. 2, pp. 92-100, 2012.

[14] A. Booker, D. Johnston, and M. Heinrich, "Value chains of herbal medicines-research needs and key challenges in the context of ethnopharmacology," Journal of Ethnopharmacology, vol. 140, no. 3, pp. 624-633, 2012.

[15] R. Sathre and L. Gustavsson, "Process-based analysis of added value in forest product industries," Forest Policy and Economics, vol. 11, no. 1, pp. 65-75, 2009.

[16] J. T. Mentzer, W. DeWitt, J. S. Keebler et al., "Defining supply chain management," Journal of Business Logistics, vol. 22, no. 2, pp. 1-25, 2001.

[17] J. von Geibler, K. Kristof, and K. Bienge, "Sustainability assessment of entire forest value chains: integrating stakeholder perspectives and indicators in decision support tools," Ecological Modelling, vol. 221, no. 18, pp. 2206-2214, 2010.

[18] D. Rana and M. Gregory, "Exploring the role of business support agencies in value chain management of the medical device industry," in Modelling Value, Contributions To Management Science: Selected Papers of the 1st International Conference on Value Chain Management, H. Jodlbauer, J. Olhager, and R. J. Schonberger, Eds., pp. 393-416, University of Applied Sciences in Upper Austria, School of Management, Steyr, Austria, 2012.

[19] K. Arthofer, C. Engelhardt-Nowitzki, H. P. Feichtenschlager, and D. Girardi, "Servicing individual product variants within value chains with an ontology," in Modelling Value, Contributions To Management Science: Selected Papers of the 1st International Conference on Value Chain Management, H. Jodlbauer, J. Olhager, and R. J. Schonberger, Eds., pp. 331-352, University of Applied Sciences in Upper Austria, School of Management, Steyr, Austria, 2012.

[20] G. Macfadyen, A. M. Nasr-Alla, D. Al-Kenawy et al., "Valuechain analysis - an assessment methodology to estimate Egyptian aquaculture sector performance," Aquaculture, vol. 362363, pp. 18-27, 2012.

[21] J. Venkateswaran and Y. J. Son, "Impact of modelling approximations in supply chain analysis-an experimental study," International Journal of Production Research, vol. 42, no. 15, pp. 2971-2992, 2004.

[22] M. T. Hansen, A. R. Jein, S. Hayes, and P. Bateman, English Handbook For Wood Pellet Combustion, Pelletsatlas, Denmark, 2009.

[23] S. Mani, S. Sokhansanj, X. Bi, and A. Turhollow, "Economics of producing fuel pellets from biomass," Applied Engineering in Agriculture, vol. 22, no. 3, pp. 421-426, 2006.

[24] M. Mäkelä, J. Lintunen, H.-L. Kangas, and J. Uusivuori, "Pellet promotion in the Finnish sawmilling industry: the costeffectiveness of different policy instruments," Journal of Forest Economics, vol. 17, no. 2, pp. 185-196, 2011.

[25] N. Saracoglu and G. Gunduz, "Wood pellets-tomorrow's fuel for Europe," Energy Sources A, vol. 31, no. 19, pp. 1708-1718, 2009.

[26] H. Spelter and D. Toth, North America's Wood Pellet Sector, Department of Agriculture, Forest Service, Forest Products Laboratory, Madison, Wis, USA, 2009.

[27] A. Tapaninen, Adoption of Innovation: Wood Pellet Heating System in the Renewable Residential Energy Context, Faculty of Business and Technology Management. Tampere University of Technology, Tampere, Finland, 2010.
[28] P. Åsman, Pellet Tool Kit, A Basic How-To Guide Prior To Starting Your Pellet Project, Northern Ontario Value Added Initiative, FP Innovations, Timmins, Ontario.

[29] A. Uasuf and G. Becker, "Wood pellets production costs and energy consumption under different framework conditions in Northeast Argentina," Biomass and Bioenergy, vol. 35, no. 3, pp. 1357-1366, 2011.

[30] A. Pirraglia, R. Gonzalez, and D. Saloni, "Techno-economical analysis of wood pellets production for U.S. manufacturers," BioResources, vol. 5, no. 4, pp. 2374-2390, 2010.

[31] A. Wolf, A. Vidlund, and E. Andersson, "Energy-efficient pellet production in the forest industry - a study of obstacles and success factors," Biomass and Bioenergy, vol. 30, no. 1, pp. 3845, 2006.

[32] D. Alfonso, C. Perpiñá, A. Pérez-Navarro, E. Peñalvo, C. Vargas, and R. Cárdenas, "Methodology for optimization of distributed biomass resources evaluation, management and final energy use," Biomass and Bioenergy, vol. 33, no. 8, pp. 1070-1079, 2009.

[33] P. W. Gallagher, H. Brubaker, and H. Shapouri, "Plant size: capital cost relationships in the dry mill ethanol industry," Biomass and Bioenergy, vol. 28, no. 6, pp. 565-571, 2005.

[34] K. Mahapatra, L. Gustavsson, and R. Madlener, "Bioenergy innovations: the case of wood pellet systems in Sweden," Technology Analysis and Strategic Management, vol. 19, no. 1, pp. 99-125, 2007.

[35] N. Kaliyan and R. Vance Morey, "Factors affecting strength and durability of densified biomass products," Biomass and Bioenergy, vol. 33, no. 3, pp. 337-359, 2009.

[36] A. Sultana, A. Kumar, and D. Harfield, "Development of agripellet production cost and optimum size," Bioresource Technology, vol. 101, no. 14, pp. 5609-5621, 2010.

[37] A. Pa, X. T. Bi, and S. Sokhansanj, "A life cycle evaluation of wood pellet gasification for district heating in British Columbia," Bioresource Technology, vol. 102, no. 10, pp. 61676177, 2011.

[38] A. Sultana and A. Kumar, "Ranking of biomass pellets by integration of economic, environmental and technical factors," Biomass and Bioenergy, vol. 39, pp. 344-355, 2012.

[39] S. Naik, V. V. Goud, P. K. Rout, K. Jacobson, and A. K. Dalai, "Characterization of Canadian biomass for alternative renewable biofuel," Renewable Energy, vol. 35, no. 8, pp. 1624$1631,2010$.

[40] I. Obernberger and G. Thek, "Physical characterisation and chemical composition of densified biomass fuels with regard to their combustion behaviour," Biomass and Bioenergy, vol. 27, no. 6, pp. 653-669, 2004.

[41] AEBIOM (European Biomass Association), 2013, ENplus, AEBIOM, Brussels, Belgium, http://www.enplus-pellets.eu/.

[42] A. García-Maraver, V. Popov, and M. Zamorano, "A review of European standards for pellet quality," Renewable Energy, vol. 36, no. 12, pp. 3537-3540, 2011.

[43] PFI (Pellet Fuels Institute), Pellet Fuels Institute Standard Specification For Residential/Commercial Densified Fuel, PFI, Arlington, Va, USA, 2011.

[44] EPC (European Pellet Council), EN Plus: European Pellet Council Handbook For the Certification of Wood Pellets For Heating Purposes, Version 2.0., European PelletCouncil, European Biomass Association, Brussels, Belgium, 2013.

[45] WPAC (Wood Pellet Association of Canada), Sustainable Biomass Production, Annex Business Media, 2013, http:// www.pellet.org/wpac-news/sustainable-biomass-Production. 
[46] AEBIOM (European Biomass Association), ENplus Newsletter, AEBIOM, Brussels, Belgium, 2012.

[47] G. Kayakutlu and G. Buyukozkan, "Assessing performance factors for a 3PL in a value chain," International Journal of Production Economics, vol. 131, no. 2, pp. 441-452, 2011.

[48] A. I. Pettersson and A. Segerstedt, "Measuring supply chain cost," International Journal of Production Economics, vol. 143, no. 2, pp. 357-363, 2012.

[49] M. Panley and S. Boerner, Demand-Driven Supply Networks: Advancing Supply Chain Management, SAP AG, Germany, 2006.

[50] W. Klibi, A. Martel, and A. Guitouni, "The design of robust value-creating supply chain networks: a critical review," European Journal of Operational Research, vol. 203, no. 2, pp. 283293, 2010.

[51] S. Gold and S. Seuring, "Supply chain and logistics issues of bioenergy production," Journal of Cleaner Production, vol. 19, no. 1, pp. 32-42, 2011.

[52] C. N. Rail, 2012, Wood Pellets, http://www.cn.ca/en/shippingalternative-energy-products-wood-pellets.htm.

[53] M. S. Pishvaee, M. Rabbani, and S. A. Torabi, "A robust optimization approach to closed-loop supply chain network design under uncertainty," Applied Mathematical Modelling, vol. 35, no. 2, pp. 637-649, 2011.

[54] J. Godsell, T. Diefenbach, C. Clemmow, D. Towill, and M. Christopher, "Enabling supply Chain segmentation through demand profiling," International Journal of Physical Distribution and Logistics Management, vol. 41, no. 3, pp. 296-314, 2011.

[55] D. Ivanov, B. Sokolov, and J. Kaeschel, "A multi-structural framework for adaptive supply chain planning and operations control with structure dynamics considerations," European Journal of Operational Research, vol. 200, no. 2, pp. 409-420, 2010.

[56] F. Pan and R. Nagi, "Robust supply chain design under uncertain demand in agile manufacturing," Computers and Operations Research, vol. 37, no. 4, pp. 668-683, 2010.

[57] A. D. Yimer and K. Demirli, "A genetic approach to two-phase optimization of dynamic supply chain scheduling," Computers and Industrial Engineering, vol. 58, no. 3, pp. 411-422, 2010.

[58] A. Gunasekaran and E. W. T. Ngai, "The future of operations management: an outlook and analysis," International Journal of Production Economics, vol. 135, no. 2, pp. 687-701, 2012.

[59] M. E. Kreye, Y. M. Goh, L. B. Newnes, and P. Goodwin, "Approaches to displaying information to assist decisions under uncertainty," Omega, vol. 40, no. 6, pp. 682-692, 2012.

[60] L. G. Papageorgiou, "Supply chain optimisation for the process industries: advances and opportunities," Computers and Chemical Engineering, vol. 33, no. 12, pp. 1931-1938, 2009.

[61] M. Christopher and D. R. Towill, "Supply chain migration from lean and functional to agile and customised," Supply Chain Management, vol. 5, no. 4, pp. 206-213, 2000.

[62] C. Neumann, S. Kohlhuber, and S. Hanusch, "Lean production Austrian industrial companies: an empirical investigation," in Modelling value, Contributions to Management Science: selected papers of the 1st International Conference on Value Chain Management, H. Jodlbauer, J. Olhager, and R. J. Schonberger, Eds., pp. 293-312, University of Applied Sciences in Upper Austria, School of Management, Steyr, Austria, May 2012.

[63] J. Olhager and D. I. Prajogo, "The impact of manufacturing and supply chain improvement initiatives: a survey comparing make-to-order and make-to-stock firms," Omega, vol. 40, no. 2, pp. 159-165, 2012.
[64] R. J. Schonberger, "Measurement of lean value chains: efficiency and effectiveness," in Modelling value, Contributions to Management Science: selected papers of the 1st International Conference on Value Chain Management, H. Jodlbauer, J. Olhager, and R. J. Schonberger, Eds., pp. 65-75, University of Applied Sciences in Upper Austria, School of Management, Steyr, Austria, May 2012.

[65] J. Blackburn, "Valuing time in supply chains: establishing limits of time-based competition," Journal of Operations Management, vol. 30, no. 5, pp. 396-405, 2012.

[66] E. W. T. Ngai, D. C. K. Chau, and T. L. A. Chan, "Information technology, operational, and management competencies for supply chain agility: findings from case studies," Journal of Strategic Information Systems, vol. 20, no. 3, pp. 232-249, 2011.

[67] J. M. Rudd, G. E. Greenley, A. T. Beatson, and I. N. Lings, "Strategic planning and performance: extending the debate," Journal of Business Research, vol. 61, no. 2, pp. 99-108, 2008.

[68] P. Schütz and A. Tomasgard, "The impact of flexibility on operational supply chain planning," International Journal of Production Economics, vol. 134, no. 2, pp. 300-311, 2011.

[69] C. Wu and D. Barnes, "A literature review of decision-making models and approaches for partner selection in agile supply chains," Journal of Purchasing and Supply Management, vol. 17, no. 4, pp. 256-274, 2011.

[70] M. Gooch, "Evaluating the effectiveness of experiential learning for motivating value chain stakeholders to adopt new ways of capturing value," in Proceedings of the 1st International Conference on Value Chain Management Modelling value, Contributions to Management Science, H. Jodlbauer, J. Olhager, and R. J. Schonberger, Eds., pp. 49-64, University of Applied Sciences in Upper Austria, School of Management, Steyr, Austria, May 2012.

[71] J. Kraigher-Krainer, "Habit, affect and cognition: a constructivist model on how they shape decision making," in Proceedings of the 1st International Conference on Value Chain Management Modelling value, Contributions to Management Science, $\mathrm{H}$. Jodlbauer, J. Olhager, and R. J. Schonberger, Eds., pp. 189-206, University of Applied Sciences in Upper Austria, School of Management, Steyr, Austria, May 2012.

[72] C. Öberg, "What happened with the grandiose plans? Strategic plans and network realities in B2B interaction," Industrial Marketing Management, vol. 39, no. 6, pp. 963-974, 2010.

[73] C. Engelhardt-Nowitzki, K. Arthofer, N. Kryvinska, and C. Strauss, "Supporting value chain integration through ontologybased modeling," in Proceedings of the 6th International Conference on Complex, Intelligent, and Software Intensive Systems, L. Barolli, F. Xhafa, S. Vitabile, and M. Uehara, Eds., IEEE Computer Society, Sanpaolo Palace Hotel, Palermo, Italy, July 2012.

[74] D. E. Cantor and J. R. Macdonald, "Decision-making in the supply chain: examining problem solving approaches and information availability," Journal of Operations Management, vol. 27, no. 3, pp. 220-232, 2009.

[75] Subramanian, B. G. P. S, and V. S. Reddy, "Transforming data driven SCM to demand driven SCM through lead time optimization," in Ninth AIMS International Conference on Management, Pune, India, January 2012.

[76] H. An, W. E. Wilhelm, and S. W. Searcy, "Biofuel and petroleumbased fuel supply chain research: a literature review," Biomass and Bioenergy, vol. 35, no. 9, pp. 3763-3774, 2011. 
[77] C. Chandra and S. Kumar, "Supply chain management in theory and practice: a passing fad or a fundamental change?" Industrial Management and Data Systems, vol. 100, no. 3, pp.100-113, 2000.

[78] K. J. Mizgier, S. M. Wagner, and J. A. Holyst, "Modeling defaults of companies in multi-stage supply chain networks," International Journal of Production Economics, vol. 135, no. 1, pp. 14-23, 2012.

[79] A. Toppinen and J. Kuuluvainen, "Forest sector modelling in Europe-the state of the art and future research directions," Forest Policy and Economics, vol. 12, no. 1, pp. 2-8, 2010.

[80] M. Singer and P. Donoso, "Upstream or downstream in the value chain?” Journal of Business Research, vol. 61, no. 6, pp. 669-677, 2008.

[81] C. Li, "Toward full, multiple, and optimal wood fibre utilization: a modeling perspective," Forestry Chronicle, vol. 85, no. 3, pp. 377-381, 2009.

[82] S. Yousefi, M. P. Moghaddam, and V. J. Majd, "Optimal real time pricing in an agent-based retail market using a comprehensive demand response model," Energy, vol. 36, no. 9, pp. 5716-5727, 2011.

[83] N. Ayoub and N. Yuji, "Demand-driven optimization approach for biomass utilization networks," Computers and Chemical Engineering, vol. 36, no. 1, pp. 129-139, 2012.

[84] T. Wöhrle, "Supply chain at western digital," Supply Chain Europe, vol. 18, no. 3, pp. 46-47, 2009.

[85] N. Ayoub, H. Seki, and Y. Naka, "Superstructure-based design and operation for biomass utilization networks," Computers and Chemical Engineering, vol. 33, no. 10, pp. 1770-1780, 2009.

[86] J. Vinterbäck, "Pell-Sim-dynamic model for forecasting storage and distribution of wood pellets," Biomass and Bioenergy, vol. 27, no. 6, pp. 629-643, 2004.

[87] T. Hosoda and S. M. Disney, "A delayed demand supply chain: incentives for upstream players," Omega, vol. 40, no. 4, pp. 478487, 2012.

[88] J. R. Trapero, N. Kourentzes, and R. Fildes, "Impact of information exchange on supplier forecasting performance," Omega, vol. 40, no. 6, pp. 738-747, 2012.

[89] B. Hillring and J. Vinterbäck, "Wood pellets in the Swedish residential market," Forest Products Journal, vol. 48, no. 5, pp. 67-72, 1998.

[90] R. E. Löfstedt, "The use of biomass energy in a regional context: the case of Vaxjo Energi, Sweden," Biomass and Bioenergy, vol. 11, no. 1, pp. 33-42, 1996.

[91] E. Alakangas, M. Junginger, J. van Dam et al., "EUBIONET IIISolutions to biomass trade and market barriers," Renewable and Sustainable Energy Reviews, vol. 16, no. 6, pp. 4277-4290, 2012.

[92] M. Cocchi, L. Nikolaisen, M. Junginger et al., Global Wood Pellet Industry Market and Trade Study, IEA Bioenergy, Task 40: Sustainable International Bioenergy Trade, Utrecht University, 2011.

[93] L. Schroeder, Go Pellets Canada Pushes Domestic Market Sales, Canadian Bioenergy Association, Ottawa, Canada, 2011.

[94] C. Verhoest and Y. Ryckmans, Industrial Wood Pellets Report, PellCert, 2012.

[95] D. Bradley and K. Bradburn, Economic Impact of Bioenergy in Canada, Canadian Bioenergy Association, 2012.

[96] D. Bradley and E. Thiffault, IEA Bioenergy Task 40 Country Report, Canada, Canadian Bioenergy Association, 2012.

[97] M. Selkimäki, B. Mola-Yudego, D. Röser, R. Prinz, and L. Sikanen, "Present and future trends in pellet markets, raw materials, and supply logistics in Sweden and Finland," Renewable and Sustainable Energy Reviews, vol. 14, no. 9, pp. 3068-3075, 2010.

[98] M. Junginger, J. van Dam, S. Zarrilli, F. Ali Mohamed, D. Marchal, and A. Faaij, "Opportunities and barriers for international bioenergy trade," Energy Policy, vol. 39, no. 4, pp. 2028-2042, 2011.

[99] P. J. Ince, A. D. Kramp, K. E. Skog, D.-I. Yoo, and V. A. Sample, "Modeling future U.S. forest sector market and trade impacts of expansion in wood energy consumption," Journal of Forest Economics, vol. 17, no. 2, pp. 142-156, 2011.

[100] P. Lamers, M. Junginger, C. Hamelinck, and A. Faaij, "Developments in international solid biofuel trade-an analysis of volumes, policies, and market factors," Renewable and Sustainable Energy Reviews, vol. 16, no. 5, pp. 3176-3199, 2012.

[101] N. Lu and R. W. Rice, "Characteristics of wood fuel pellet manufacturers and markets in the united states, 2010," Forest Products Journal, vol. 61, no. 4, pp. 310-315, 2011.

[102] V. Karkania, E. Fanara, and A. Zabaniotou, "Review of sustainable biomass pellets production-a study for agricultural residues pellets' market in Greece," Renewable and Sustainable Energy Reviews, vol. 16, no. 3, pp. 1426-1436, 2012.

[103] E. Monteiro, V. Mantha, and A. Rouboa, "Portuguese pellets market: analysis of the production and utilization constrains," Energy Policy, vol. 42, pp. 129-135, 2012.

[104] J.-H. Moon, J.-W. Lee, and U.-D. Lee, "Economic analysis of biomass power generation schemes under renewable energy initiative with Renewable Portfolio Standards (RPS) in Korea," Bioresource Technology, vol. 102, no. 20, pp. 9550-9557, 2011.

[105] O. Olsson, B. Hillring, and J. Vinterbäck, "European wood pellet market integration - a study of the residential sector," Biomass and Bioenergy, vol. 35, no. 1, pp. 153-160, 2011.

[106] B. M. Sopha, C. A. Klöckner, G. Skjevrak, and E. G. Hertwich, "Norwegian households' perception of wood pellet stove compared to air-to-air heat pump and electric heating," Energy Policy, vol. 38, no. 7, pp. 3744-3754, 2010.

[107] E. Trømborg, M. Havskjold, O. Lislebø, and P. K. Rørstad, "Projecting demand and supply of forest biomass for heating in Norway," Energy Policy, vol. 39, no. 11, pp. 7049-7058, 2011.

[108] J. van Dam, A. P. C. Faaij, J. Hilbert, H. Petruzzi, and W. C. Turkenburg, "Large-scale bioenergy production from soybeans and switchgrass in Argentina. Part A: potential and economic feasibility for national and international markets," Renewable and Sustainable Energy Reviews, vol. 13, no. 8, pp. 1710-1733, 2009.

[109] V. K. Verma, S. Bram, and J. De Ruyck, "Small scale biomass heating systems: Standards, quality labelling and market driving factors-an EU outlook," Biomass and Bioenergy, vol. 33, no. 10, pp. 1393-1402, 2009.

[110] J. Palladini, Canada's Wood Products Industry, Conference Board of Canada, Ottawa, Canada, 2010.

[111] A. Yatchew and A. Baziliauskas, "Ontario feed-in-tariff programs," Energy Policy, vol. 39, no. 7, pp. 3885-3893, 2011.

[112] J. Krupa, "Blazing a new path forward: a case study on the renewable energy initiatives of the Pic River First Nation," Environmental Development, vol. 3, pp. 109-122, 2012.

[113] V. Uran, "A model for establishing a win-win relationship between a wood pellets manufacturer and its customers," Biomass and Bioenergy, vol. 34, no. 5, pp. 747-753, 2010.

[114] S. van Dyken, B. H. Bakken, and H. I. Skjelbred, "Linear mixed-integer models for biomass supply chains with transport, storage and processing," Energy, vol. 35, no. 3, pp. 1338-1350, 2010. 
[115] N. Shabani and T. Sowlati, "A mixed integer non-linear programming model for tactical value chain optimization of a wood biomass power plant," Applied Energy, vol. 104, pp. 353361, 2013.

[116] V. Christensen, J. Steenbeek, and P. Failler, "A combined ecosystem and value chain modeling approach for evaluating societal cost and benefit of fishing," Ecological Modelling, vol. 222, no. 3, pp. 857-864, 2011.

[117] A. Oo, J. Kelly, and C. Lalonde, Assessment of Business Case For Purpose-Grown Biomass in Ontario, The Western University Research Park, Sarnia, Canada, 2012.

[118] K. Campbell, A Feasibility Study Guide For An Agricultural Biomass Pellet Company, Agricultural Utilization Research Institute, St. Paul, Minn, USA, 2007.

[119] BW McCloy \& Associates, NWT Wood Pellet Pre-Feasibility Analysis, FPInnovations, Forintek Division, 2009.

[120] G. Murray, Lillooet Biomass Energy Corporation Business Plan for a Wood Pellet Plant, Gordon Murray Corporate Finance, Revelstoke, Canada, 2010.

[121] NEOS Corporation, Wood Pelletization Sourcebook: A Sample Business Plan For the Potential Pellet Manufacturer, Report No. DE-FG05-83R21390 (44), Great Lakes Regional Biomass Energy Program, 1995.

[122] G. Blom, The feasibility of a wood pellet plant using alternate sources of wood fibre [B.Sc.F. thesis], University of British Columbia, Vancouver, Canada, 2009.

[123] A. Ravn and S. P. Engstrøm, Modelling of wood pellet production and distribution for energy consumption [M.S. thesis], Technical University of Denmark, DTU Management Engineering, Kongens Lyngby, Denmark, 2010.

[124] E. Urbanowski, Strategic analysis of a pellet fuel opportunity in Northwest British Columbia [M.B.A. thesis], Simon Fraser University,, 2005.

[125] A. Kumar, J. B. Cameron, and P. C. Flynn, "Biomass power cost and optimum plant size in western Canada," Biomass and Bioenergy, vol. 24, no. 6, pp. 445-464, 2003.

[126] B. M. Jenkins, "A comment on the optimal sizing of a biomass utilization facility under constant and variable cost scaling," Biomass and Bioenergy, vol. 13, no. 1-2, pp. 1-9, 1997.

[127] F. Nasiri and G. Zaccour, "An exploratory game-theoretic analysis of biomass electricity generation supply chain," Energy Policy, vol. 37, no. 11, pp. 4514-4522, 2009.

[128] M. Mobini, T. Sowlati, and S. Sokhansanj, "Forest biomass supply logistics for a power plant using the discrete-event simulation approach," Applied Energy, vol. 88, no. 4, pp. 12411250, 2011.

[129] M. Mahnam, M. R. Yadollahpour, V. Famil-Dardashti, and S. R. Hejazi, "Supply chain modeling in uncertain environment with bi-objective approach," Computers and Industrial Engineering, vol. 56, no. 4, pp. 1535-1544, 2009.

[130] S. Sokhansanj, A. Turhollow, and E. Wilkerson, "Integrated biomass supply and logistics," Resource, vol. 15, no. 6, pp. 15-18, 2008.

[131] M. B. Alam, R. Pulkki, C. Shahi, and T. Upadhyay, "Modeling woody biomass procurement for bioenergy production at the Atikokan Generating Station in Northwestern Ontario, Canada," Energies, vol. 5, no. 12, pp. 5065-5085, 2012.

[132] T. P. Upadhyay, C. Shahi, M. Leitch, and R. Pulkki, "Economic feasibility of biomass gasification for power generation in three selected communities of northwestern Ontario, Canada," Energy Policy, vol. 44, pp. 235-244, 2012.
[133] J. Nagel, "Determination of an economic energy supply structure based on biomass using a mixed-integer linear optimization model," Ecological Engineering, vol. 16, no. 1, pp. S91-S102, 2000.

[134] B. M. Sopha, C. A. Klöckner, and E. G. Hertwich, "Exploring policy options for a transition to sustainable heating system diffusion using an agent-based simulation," Energy Policy, vol. 39, no. 5, pp. 2722-2729, 2011.

[135] A. Sultana and A. Kumar, "Optimal siting and size of bioenergy facilities using geographic information system," Applied Energy, vol. 94, pp. 192-201, 2012.

[136] H. K. Sjølie, G. S. Latta, D. M. Adams, and B. Solberg, "Impacts of agent information assumptions in forest sector modeling," Journal of Forest Economics, vol. 17, no. 2, pp. 169-184, 2011.

[137] M. Aydinel, T. Sowlati, X. Cerda, E. Cope, and M. Gerschman, "Optimization of production allocation and transportation of customer orders for a leading forest products company," Mathematical and Computer Modelling, vol. 48, no. 7-8, pp. 1158-1169, 2008.

[138] H. Gunnarsson, M. Rönnqvist, and J. T. Lundgren, "Supply chain modelling of forest fuel," European Journal of Operational Research, vol. 158, no. 1, pp. 103-123, 2004.

[139] B. Velazquez-Marti and E. Fernandez-Gonzalez, "Mathematical algorithms to locate factories to transform biomass in bioenergy focused on logistic network construction," Renewable Energy, vol. 35, no. 9, pp. 2136-2142, 2010.

[140] H. L. Lam, P. S. Varbanov, and J. J. Klemeš, "Optimisation of regional energy supply chains utilising renewables: p-graph approach," Computers and Chemical Engineering, vol. 34, no. 5, pp. 782-792, 2010.

[141] P. C. Jones and J. W. Ohlmann, "Long-range timber supply planning for a vertically integrated paper mill," European Journal of Operational Research, vol. 191, no. 2, pp. 557-570, 2008.

[142] D. Carlsson and M. Rönnqvist, "Supply chain management in forestry-case studies at Södra Cell AB," European Journal of Operational Research, vol. 163, no. 3, pp. 589-616, 2005.

[143] S. S. Pitty, W. Li, A. Adhitya, R. Srinivasan, and I. A. Karimi, "Decision support for integrated refinery supply chains. Part 1. Dynamic simulation," Computers and Chemical Engineering, vol. 32, no. 11, pp. 2767-2786, 2008.

[144] L. Y. Koo, A. Adhitya, R. Srinivasan, and I. A. Karimi, “Decision support for integrated refinery supply chains. Part 2. Design and operation," Computers and Chemical Engineering, vol. 32, no. 11, pp. 2787-2800, 2008.

[145] O. Ahumada and J. R. Villalobos, "Operational model for planning the harvest and distribution of perishable agricultural products," International Journal of Production Economics, vol. 133, no. 2, pp. 677-687, 2011.

[146] X. Fang, C. Zhang, D. J. Robb, and J. D. Blackburn, "Decision support for lead time and demand variability reduction," Omega, vol. 41, no. 2, pp. 390-396, 2012.

[147] C. A. Garcia, A. Ibeas, J. Herrera, and R. Vilanova, "Inventory control for the supply chain: an adaptive control approach based on the identification of the lead-time," Omega, vol. 40, no. 3, pp. 314-327, 2012.

[148] C. Li and S. Liu, "A stochastic network model for ordering analysis in multi-stage supply chain systems," Simulation Modelling Practice and Theory, vol. 22, pp. 92-108, 2012. 
[149] K. Mitra, R. D. Gudi, S. C. Patwardhan, and G. Sardar, "Towards resilient supply chains: uncertainty analysis using fuzzy mathematical programming," Chemical Engineering Research and Design, vol. 87, no. 7, pp. 967-981, 2009.

[150] C. Gomes da Silva, J. Figueira, J. Lisboa, and S. Barman, "An interactive decision support system for an aggregate production planning model based on multiple criteria mixed integer linear programming," Omega, vol. 34, no. 2, pp. 167-177, 2006.

[151] P. Luathep, A. Sumalee, W. H. K. Lam, Z.-C. Li, and H. K. Lo, "Global optimization method for mixed transportation network design problem: a mixed-integer linear programming approach," Transportation Research B, vol. 45, no. 5, pp. 808-827, 2011.

[152] P. K. Naraharisetti, I. A. Karimi, and R. Srinivasan, "Supply chain redesign through optimal asset management and capital budgeting," Computers and Chemical Engineering, vol. 32, no. 12, pp. 3153-3169, 2008.

[153] G. J. Hahn and H. Kuhn, "Designing decision support systems for value-based management: a survey and an architecture," Decision Support Systems, vol. 53, no. 3, pp. 591-598, 2012.

[154] A. Sadegheih and P. R. Drake, "System network planning expansion using mathematical programming, genetic algorithms and tabu search," Energy Conversion and Management, vol. 49, no. 6, pp. 1557-1566, 2008.

[155] H. J. Ko and G. W. Evans, "A genetic algorithm-based heuristic for the dynamic integrated forward/reverse logistics network for 3PLs," Computers and Operations Research, vol. 34, no. 2, pp. 346-366, 2007.

[156] M. Bashiri, H. Badri, and J. Talebi, "A new approach to tactical and strategic planning in production-distribution networks," Applied Mathematical Modelling, vol. 36, no. 4, pp. 1703-1717, 2012. 


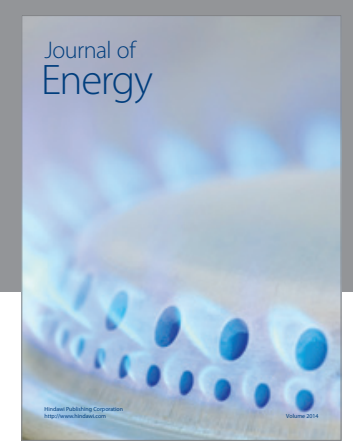

Journal of

Industrial Engineering
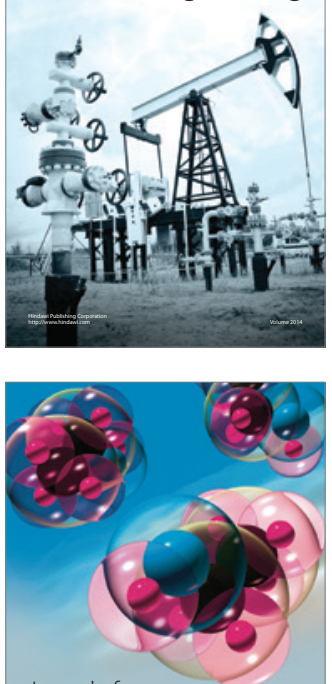

Fuels
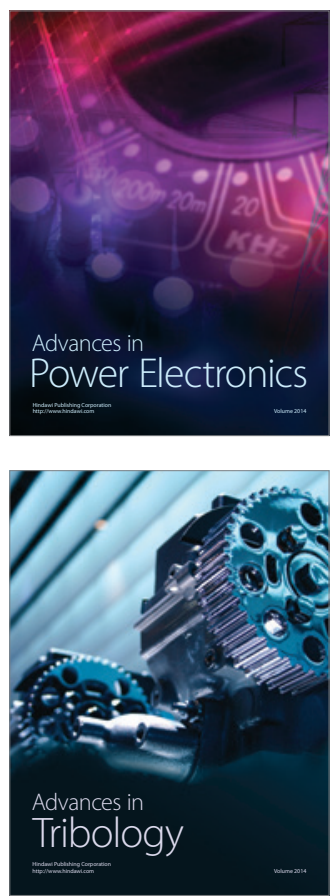

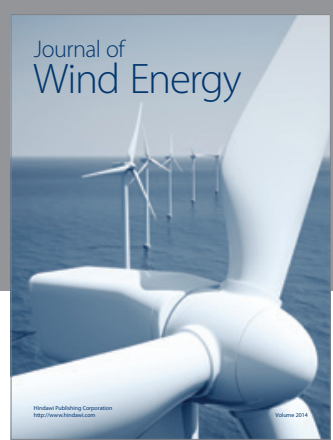

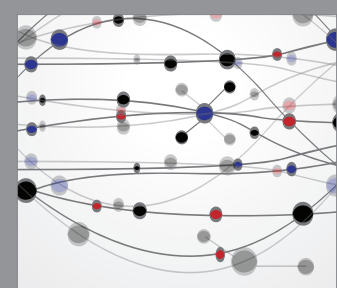

The Scientific World Journal

Submit your manuscripts at http://www.hindawi.com

Journal of

Structures
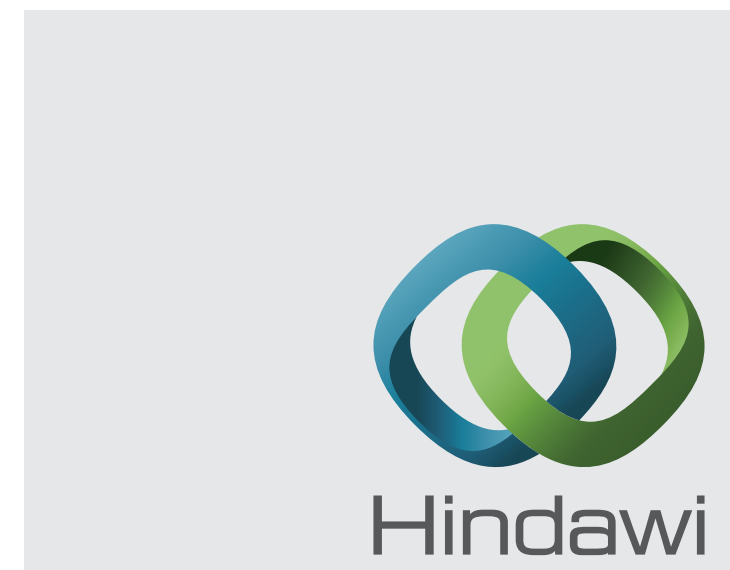

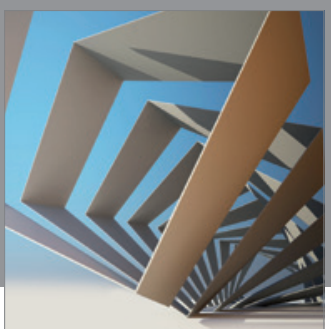

Rotating

Machinery
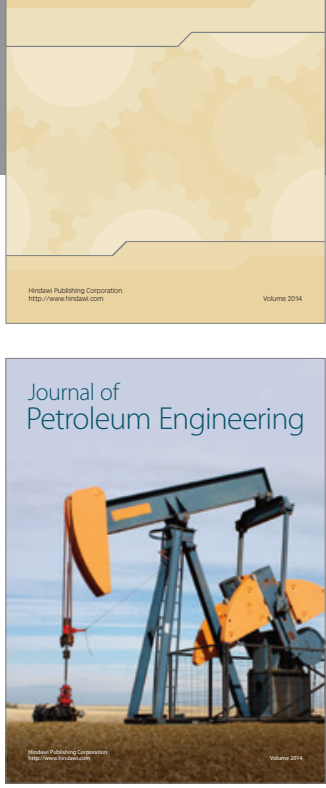

Journal of

Solar Energy
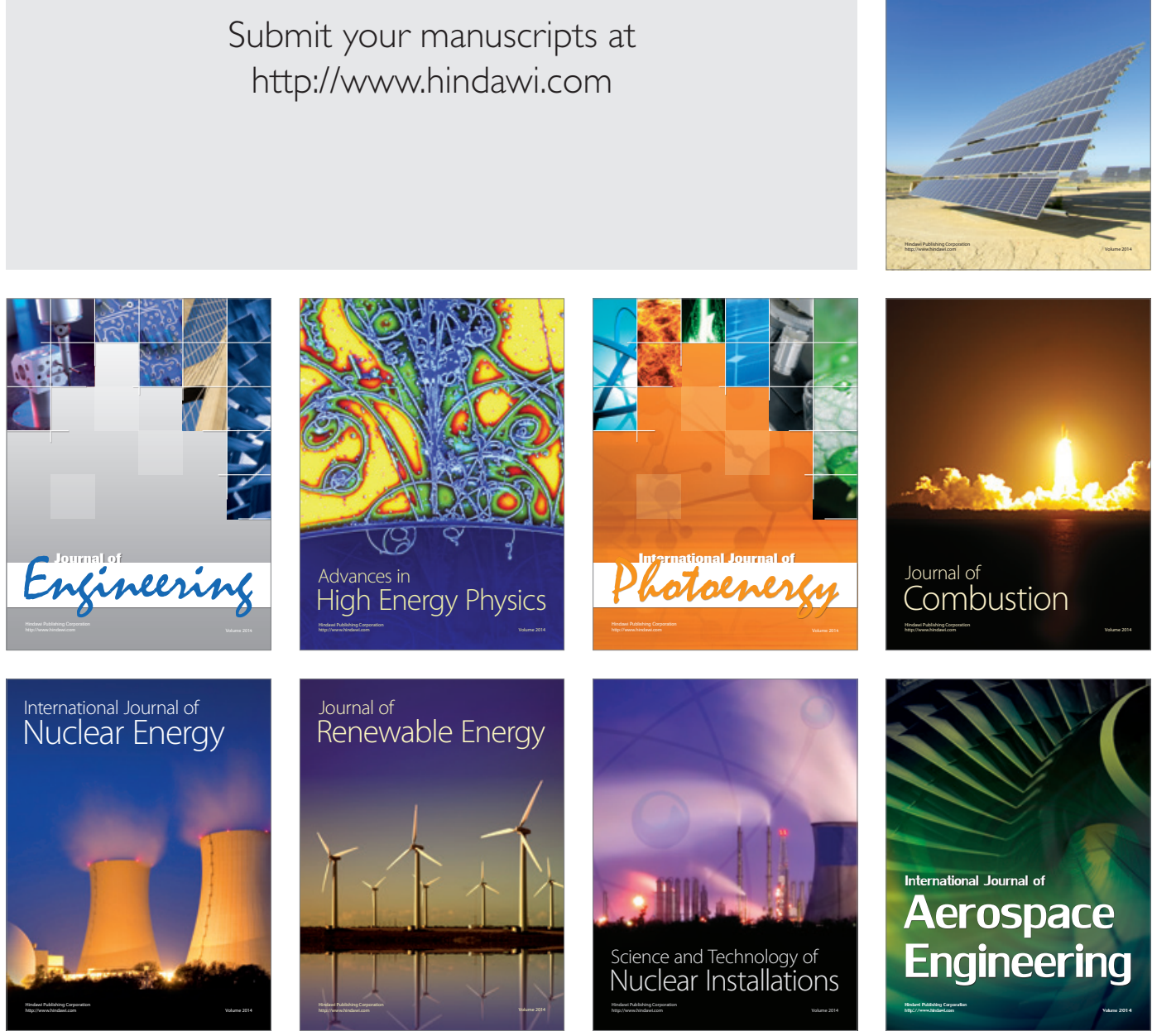